\title{
The Importance Of Moral Value Through Law Enforcement In Indonesia In Nonsystematic Legal Approach
}

\author{
Siti Zuliyah \\ Universitas Ahmad Dahlan \\ siti.zuliyah@law.uad.ac.id
}

DOI: https://doi.org/10.23917/jtl.v1i2.9104

\section{Submission \\ Track:}

Received:

26 Oktober 2019

Final Revision:

5 Februari 2020

Available online:

14 Februari 2020

Corresponding

Author:

Siti Zuliyah

siti.zuliyah@law.uad.ac.id

\begin{abstract}
Purpose: This writing is purposed to explore the importance of moral value through law enforcement in Indonesia as basic dispensing justice, which is essential through a nonsystematic legal approach.

Methodology: This research using the philosophical approach method, which is purposed to explore the importance of moral value through law enforcement. As it for the method used in this research is descriptive, then proceeded in interpretive.

Findings: Nonsystematical legal approach views that jurisprudence is living and developing behavior patterns in society so that between law and moral can not be separated. In relation to the importance of moral value through law enforcement is intended as guidelines for law enforcement officer in the act of implementing their job well and responsibly, so that can give justice.
\end{abstract}

Importance: This research can help explain the importance of moral value through law enforcement so that can be a formulation of regulation or guidelines for law enforcement officer about how should take action in implementing law enforcement that becomes responsible properly.

Originality: In relation to law enforcement in Indonesia, have been struggling at the positivist paradigm or systematic that bring law out of value and religion, so that just being instrumentalist tools. Therefore needed a new approach by accommodate moral value and religion to law enforcement optimized.

Keywords: Moral Value, Law Enforcement, Nonsystematic Legal Approach 


\section{INTRODUCTION}

In practice of law enforcement, the principle of justice, accuracy, and courtesy are fundamental that has to guidance by a law enforcer. Several pameo, the slogan from unfolding issue in society which is related to law enforcement that has promoted a gap between the theory and practice. For example, appear pameo, the law is blunt upward, sharply downward, there is law enforcer who does cut down select in law enforcement, the law can be bought, justice as expensive things and many terms that weaken law in Indonesia.

We can see there is a systematic game which is played by those responsible for law executor in a court. Judicial in Indonesia considered has given immoral birth judges, like Sudi Wardiono case, chief of Manado High Court is an ironic example from the head of court officer, which should be role model but rather be corruptor. Our law has been mottled, and many more cases which are happened because of misappropriation of verdict implementation. It seems like Minah's case which is punished by PN Purwokerto because of stated innocence reaping cocoa in PT. Rumpun Sari Anton plantation. Moreover, there is adjudication as money producing fields, like Akil Mochtar case. From these various cases, no wonder if society cynical to see law enforcement officers because of loss of their belief, on the assumption that justice is only used for the major capital owners who can buy supremacy.

Positivism paradigm or systematic flow go the way to teach that law is regulating, apply a whole, and established by authority of the country. According to Hans Kelsen, ${ }^{1}$ Law is described as a sterile domain (free of value), separated from ethical and moral. Law enforcement in Indonesia during this time struggling at positivism paradigm or systematic that makes law separated from moral value and religion, so that just has become an instrumentalists tools, a funnel of constitution and knocker of the hammer from article text which is formulated in area of power space so that far from a sense of justice.

Satjipto Rahardjo Criticized the law enforcement in Indonesia, First of them, enforcement of the laws that move in constitution supremacy and rhetoric supremacy of law state. Whereas, the spirit of justice, honesty, and authenticity of law enforcement

\footnotetext{
1 Absori, Ahmadi, "Transplantasi Niilai Moral Dalam Budaya Untuk Menuju Hukum Berkeadilan (Prespektif Hukum Sistematik ke Non Sistematik Charles Sampford), Prosiding Konferensi Nasional ke 6 Asosiasi Perogram Pasca Sarjana Perguruan Tinggi Muhammadiyah (APPPTM) Yogyakarta2017
} 
which has been thin and disappear. Indonesia, still called as a law state actually has experienced of derogation that serious and worst. Secondly, law enforcement that moves the slow lane. The resolution process law that takes a long time, convoluted and spent many costs. In this case, Satjipto Criticises the game of money in case a solution. Thirdly, law enforcement in Indonesia has lost its moral Legitimation. Due to law enforcement, which had been traded. Fourthly, law enforcement is not proportional to discipline. Discipline is one of the orientations of law enforcement, but in Indonesia, due to there is a void selection of its social aspects, law not obeyed by society. Fifthly, law enforcement, which is too dominative and does not use sociological strategic, so that occurred is law enforcement that full of corruption. ${ }^{2}$

In general, criticism that revealed by Sutjipto Rahardjo is about law enforcement in Indonesia which is not oriented on human interest and citizen. According to him, the law is for humans, not reverse. The existence of law has nothing for him but something expansive that is for human dignity, happiness, welfare, and human glory. ${ }^{3}$ Besides of that, Satjipto is restless with law enforcement, which is too formalistic and marginality against a solution, which is the living law dimension. Law for him is not the only absolute institutions and final, due to the law as a process, the law in the making. ${ }^{4}$ So that solution by formal lane doesn't need to be forced if its existence no needed or incriminating to the society.

Based on the result of research by Khudzaifah Dimyati etc. ${ }^{5}$ about judge profile through Enforcing majesty, dignity and professional honor, conclude that:

Firstly, seen through ontology aspect, all of the judges declare that law concept which is used of law as legislation, it's just there are 13 the judge who declares that law concept that used is not only law as legislation, but in a certain condition also based on law concept as value which is prevailed in society.

Secondly, seen through the epistemology aspect, all of the judges declare that reflect logic used is deductive reflect logic, but there are 9 judges declare that logic reflects

\footnotetext{
${ }^{2}$ Satjipto Raharjo,2003. Sisi lain dari hukum di Indonesia. Jakarta. Buku Kompas.

${ }^{3}$ Satjipto Raharjo, 2006. Membedah hukum progresif. Jakarta. Kompas

${ }^{4}$ Satjipto Rahadjo, 2002. Indonesia inginkan penegak hukum progresif. Kompas

${ }^{5}$ K. Dimyati, Absori, K Wardiono, "Pemetaan Dan Jasa hakim" Profil Hakim Dalam Penegakan keluhuran, Martabat dan Kehormatan Profesi. Proseding Konferesnsi Nasional Ke 2 Asosiasi Program Pasca Sarjana Perguruan Tinggi Muhammadiyah (APPPTM) Yogyakarta 2015
} 
used is not only deductive logic but also inductive logic. In this case, there is one judge who declares that reflect logic which used is inductive.

Thirdly, seen from axiology, there are six judges who declare that good judgment is Decisions which are in accordance with applicable regulations, four judges declare that good judgment is judgment that accordance with valid valued in society (Reflecting the value of justice in society ), and there is 8 judge declare that the good judgment is judgment that accordance with valid valued in society (Reflecting the value of justice in society).

The existence of law enforcement that is so fundamental, so that the position should be hard thought for determining right judgment, civilized, and fair. Caretaker of law is not justified only notice consideration on articles, but have to review social dimension and humanity in a case.

Depend on the description above show that there is a crisis problematic of moral sense through law enforcer in Indonesia. So that the law enforcer who emerging is law enforcer of being stagnant, centralized, corruptive and so far from humanist values. This writing context will try explaining the importance of moral value in law enforcement in Indonesia through the approach of non-systematic law.

\section{FORMULATION OF PROBLEM}

Depend on the description above so that this research will discuss the problem as follows:

1. How is law enforcement depend on the approach of systematic law?

2. How is law enforcement depend on the approach of non-systematic law?

3. Why is the moral value needed through law enforcement in Indonesia?

\section{METHOD OF RESEARCH}

This research using a philosophic approach, which is purposed for exploring the importance of moral value through enforcement law in Indonesia by the approach of nonsystematic law, which is the end of the purpose, can give fundamental justice. Nonsystematic approach refers to the thought of Edward O. Wilson about law Consilience and asymmetric law from Charles Sampford. This writing uses a descriptive analysis method then processed in interpretive about the importance of values in law enforcement. 
Journal of Transcendental Law

Vol. 1, No. 2, 2019, pp. 159-174

http://journals.ums.ac.id/index.php/jtl/article/view/9104 


\section{DISCUSSION}

\section{A. Moral Value in Law}

Lawrence Meil Friedman assumed that Law in this country is undoubtedly powerless, like dead fish. If not backed by legal culture, own nation. ${ }^{6}$

Law for a human being, ${ }^{7}$ it means that the rule of law cannot regardless of a human being. It is found that the rule of law cannot be separated from legal culture, because of the nation and law not only a set of institutions that are empty of social interpretation but the construction of culture. ${ }^{8}$ Law connection struggling at human (anthropocentric) from, by and for a human being. More abstract, law construction is embryonic from the mind and human experience, which presents justice.

Culture in law is the fundamental value of human, which is leashing. Therefore in the assessment of problems, value need assessed and comprehended. The other important thing that value is an important element in the life of inherent humans in their life cannot be separated from values. Therefore, these values are very wide, can found in a range of chosen behavior through a variety of life which is wide in this universe. ${ }^{9}$ Similarly with moral value is part of Standard mannerisms, which is functioned as Frame of Reference from interaction result.

Moral value in its practice can be subjective and objective. In subjective moral value is considered as feeling expression or someone's desire. Subjective moral value exists in nature metaphysics, its natural human mind and depends on deals between someone an adherent to that being object to the review. While the objective moral value that moral value exists in the world and had to be investigated by radical thought, which is integrated with five senses support. Considered objective because on that value there is hierarchy value. Till the good value or high, which determines structured arrangement. This objective value is a fundamental value that reflects

\footnotetext{
${ }^{6}$ Lawrence Meil Friedman, Law in Society; an Introduction (Prencite-Hall Fondation of Modern Sosiology Series, Eglewood Cliffts Stanford University, New Jersey, 1979. hlm:7

${ }^{7}$ Satjipto Raharjo, membedah hukum progresif, Jakarta, Penerbit Buku Kompas, 2007. Halm,.151.

${ }^{8}$ Francisco Javier Foncesca, "Dificiences of the rule Of Law an the Legal Culture, and its Relationship to Ander Development", Asian Journal of Law and Economics, 6(2), 2015, hlm.232

${ }^{9}$ Robin M. Williams, "Values: Concept of Falues" dalam The International Ecylopedia of The Social Scoiences, The Magmillan Publisher, London, 17 Vol, 1972, Editor: David L. Sills, disalin oleh konsorsium Antar-bidang Depdikbud Jakarta, 1982, hlm.251-252
} 
universality the physical condition, Social psychological, the purpose of human beings wherever it exists. ${ }^{10}$

Law consists of ethical value, that the criteria establishment of law is moral freedom. Law is a number requirement that guarantees if the will of the one adapted to the will of other persons according to common norms of freedom. Here, the law is defined as a human moral attitude. Between law and morals are close relationships, due to different norms that different in abstract, in concrete do not appear separately. Manners norm becomes law norm due to that norms valid morally, then can be used as law, so that moral norm will be effective for social life, thus between law and moral cannot be separated. ${ }^{11}$

\section{B. Law Enforcement Based on Approach of Systematic Law}

Law system in Indonesia All this time, we affected by paradigms systematic. According to Hans Kalsen, positive law is seen from the form which maintains normativity in antinomies jurisprudence for managing Human behavior as a rational creature. Law could not fair, but law still law. According to him, a law norm is not valid because it has a certain content, but due to it is made depending on the way, which is determined by something regarded (grundnom $)^{12}$. About law in text meaning which has been positive, thoughts of Hans Kelsen above reflecting two aspects, there are idealism aspect and materialism aspect. ${ }^{13}$

Text is world of meaning, needed a certain way for understanding, as it is said by Bloom, everyone should be always struggling on the text, with everything in human being have, with emotion, with envy, nostalgia, love feeling, anger, in words, should be used a weapon which is owned by human being to liven up that text and courageous. ${ }^{14}$ But, in the thought of law positivism, the text always refers to written regulation as a concrete process that has regulated and determined by top authorities. In a systematic paradigm, the law is not easily claimed with a domain of rationaldogmatic and static but is part of a domain that suffers erosion and cracking.

10 Absori, Ahmadi, “Transplantasi Niilai Moral Dalam Budaya Untuk Menuju Hukum Berkeadilan (Prespektif Hukum Sistematik ke Non Sistematik Charles Sampford) Op-Cit

${ }^{11}$ Muhammad Agus Santoso, Hukum, Moral dan Keadilan, Jakarta Kencana Prenada Media, 2012, hlm.90.

${ }^{12}$ Benard Arief Sidarta, Hukum dan logika, Bandung, Alumni, 2002, hlm. 10.

${ }^{13}$ Anthon F. Susanto, Ilmu Hukum Non Sistematis: Pondasi Filsafat Pengembangan Hukum di Indonesia, Yogyakarta, Gentha Publishing, 2010, hlm:151

${ }^{14}$ Anthon F Susanto, Ibid, hlm. 151 
Therefore, every time and any time will appear renewal of rule that will change the old rule.

The flow of law positivism is focused on formality which is based on a real project and set out from deduction with significant logic in law study. Law can be viewed as autonomous institutions and pure. Therefore, in order to have legitimate power and law valid, so that cannot and should not be disturbed with illegal aspects, like politics, economy social, and morality. Law theory of liberalism very protects someone's freedom, therefore protection against individual law important for implementing law rule. ${ }^{15}$

On the flow of positivism, the law is viewed that law is not from God or nature, but the law is birth from human itself which is based on provision for separation between law and morality. Positivism flow sets out from the way of educating that law has regulated character, a whole applied and determined by the authority of the state. Inside it, there is a gap between norm/policy with ethics/morals and between justices with law legality. ${ }^{16}$

All of the constitutions is a product from thought as something which is containing the law in a complete manner so that the judge duty just apply a provision of the constitution in systematic and linear through solve the social problem. Law is no longer conceived as a principle of meta-juridical moral which is abstract about justice principle, but something that has serving positivism as lege atau lex to guarantee legal certainty. ${ }^{17}$

\section{Law Enforcement Based On the Approach of Nonsystematic Law}

Edward O. Wilson in his book Consilience The Unity Of Knowledge as his statement: ${ }^{18}$ "If this world walks in such a way so that will stimulate Consilience knowledge, I am sure that culture effort finally will join to natural sciences and humanities science, especially art science. This subject will be two chapters of science at 21 century later. The social science will continue to split into each discipline

${ }^{15}$ Agus Raharjo, Hukum dan Dilema Pencitraan: Transisi Pradigmatis Ilmu Hukum dalam Teori dan Praktik”. Jurnal Hukum Pro Justicia. Vol. 24 No. 1 January 2006. Bandung: Faculty of law of Universitas Parahyangan.

16 Absori, Ahmadi, "Transplantasi Niilai Moral Dalam Budaya Untuk Menuju Hukum Berkeadilan (Prespektif Hukum Sistematik ke Non Sistematik Charles Sampford),Op-cit

17 Absori, Ahmadi, "Transplantasi Niilai Moral Dalam Budaya Untuk Menuju Hukum Berkeadilan (Prespektif Hukum Sistematik ke Non Sistematik Charles Sampford),Op-cit

${ }^{18}$ Edward O. Wilson, Consilience The Unity of Knowledge, (New York: Vintage Books, A Division of RandownHouse, inc). 1 ed on 99, hlm.2. 
science, with one of its part fuse become sustainability with biology, and one of another part fuse with humanity about philosophy and history till reasoning of moral, religion, comparison, and its interpretation will fuse into this knowledges. ${ }^{19}$

This Consilience gives an assumption to us about thought concept, which is different about law, just received what existed and established, with the process of selecting a new idea and comparing it to be reviewed. Consilience Wilson is positioning biology science at the highest stratum from other science. So, according to him, medical science, which is based on biology science has consilience. While the law does not have consilience, the law should be able to unite connection on human rationality, philosophy, and history so that on the element of moral and religious reasoning, comparison, and interpretation with the context of other science.

Next Charles Sampford in his book by the title The Disorder of Law: A Critique of Legal Theory, has introduced legal, which is lean on the chaos, asymmetric, and non-mechanistic in law. According to him, chaos theory in law is proceeds from critical thought about law which is previously have become the kind of law itself, due to law idea which is asymmetric in different argument, found of in the law sociology thought, especially micro law sociology, like conflict theory, interactionist, deconstructionist, and others that base its concept on chaotic situation, which is opposite against asymmetric law. ${ }^{20}$

The theory of Sampford tried to refuse a law that assumes always in stable and systematic conditions. He introduces different perspectives in obtaining truth alternatives, besides the dominant truth model so far. Sampford's theory is moved from reality, social base, and law, which is full of asymmetric relationships. This case is a basic assumption in construct Sampford law theory that he said to consist of power relations included authority relation, also unintended relation and value effect relation. Therefore the social relationship is perceived differently, so there was behavior polarization in social interaction. ${ }^{21}$

19 Absori, Ahmadi, "Transplantasi Niilai Moral Dalam Budaya Untuk Menuju Hukum Berkeadilan (Prespektif Hukum Sistematik ke Non Sistematik Charles Sampford), Prosiding Konferensi Nasional ke 6 Asosiasi

${ }^{20}$ Absori, Kelik Wardiono dan Seful Rahman, Hukum Profetik: Kritik Terhadap Paradigma Hukum Nonsistematik, Yogyakarta, genta Publising, 2015,hlm.213.

21 Absori, Kelik Wardiono dan Seful Rahman, Hukum Profetik: Kritik Terhadap Paradigma Hukum Nonsistematik. Ibid 
Based on the non-systematic legal approach that law science is living and developing from behavior patterns in society. Therefore between law and moral cannot be separated. If connected between law and moral surely have differences, the law as rule instrument and social control. While moral is a part of the good or bad value of human characteristics, which behaves subjective. However, law and morals have a very close relationship, due to actually law is a part of moral guidance which is happened by the human in their life. Therefore, in establishing rules, whether constitution or other rules in written or unwritten which is positive law should be based on good morals, included in solving law conflict also based on health morals that have final aim can give and create law harmony till reach distributed justice. ${ }^{22}$

Based on the non-systematic law approach that law enforcer unjustifiably if just noticed a development in an article, but should be review social dimension and humanity in a case. Due to in theory, absolutely have a starting-point on something, namely the relationship between humans and law. More theory shifted to regulation factor, so that assumes as a closed formal, legalistic unit, otherwise more shifted to human, the theory more opened and touch human social mosaic. ${ }^{23}$ Besides that in sociological, many of social variables which is involved in the meaning of requirements with humanity struggle, so that on the law enforcement besides work based on law norm, absolutely propped by values and moral norms in order to Judicial integrity as justice institutions and the truth operate in domains of value, so that able to give sense of justice.

\section{The Importance of Moral Values Through Law Enforcement in Indonesia}

Based on the law approach non-systematic above, therefore, the writer tries to analyze the importance of moral value through law enforcement in Indonesia.

Moral value is important in law enforcement, and Behavior is added in rules of positive law in Indonesia towards equitable law. Moral enthusiasm For a change for improvement should be supported by strategic and exact steps. ${ }^{24}$ Rest assured moral

\footnotetext{
22 Absori, Ahmadi, "Transplantasi Niilai Moral Dalam Budaya Untuk Menuju Hukum Berkeadilan (Prespektif Hukum Sistematik ke Non Sistematik Charles Sampford),Op-Cit

${ }^{23}$ Bernard L. Tanya dkk, 2010, Teori Hukum Strategi Tertib Manusia lintas Ruang dan Generasi, Yogyakarta, Genta Publising

${ }^{24}$ Bernard L. Tanya . Hukum Progresif : Prespektif Moral dan Kritis dalam "dekontruksi dan pemikiran hukum progresif" konsorsium Hukum Progresif Universitas Diponegoro, Yogyakarta Thafa Media, 2013, hlm. 44.
} 
value very abstinence to do betrayal, whispers conscience, and belief about right and good. 25

Moral value or ethics in law enforcement intended as manual or orientation utilities. ${ }^{26}$ A law enforcer (Police, attorney, Judge, and Law advisor), about how should manage behavior (take action) implement the task of law enforcement that becomes its responsibilities properly. The goal is to law enforcer can take action that responsible (do not miss orientation) dealing with various matters (values and moral norms), which is faced during the judicial process, therefore, it can give justice which is substantial to the society.

Law enforcement that full of with humanity struggle, besides work based on with norms law, should be supported by values and moral norms, therefore the judicial integrity as justice institution and the truth, really operated in domain humanitarian values. In the face various problem, a law enforcement officer can be loss orientation, because of that ethics present to Voicing what is the right thing to be done by a law enforcement officials to suspect/the defendant in the things that are related to the meaning of humanity, like the truth, honesty, Goodness, justice, freedom, happiness, and. In the justice system, protection against human dignity, Is one of the main reviews to determine attitude (orientation). Therefore, Torture and the defendant/suspects who allegedly involved a criminal can never accept as a method of investigation surely, because out of tune with human dignity

Torture of the defendant which is unexpectedly involved a criminal, never cannot accept as investigation method which is justified, due to do not aligned with human dignity (contra with the principle of humanity), not only for the defendant but also for humanity principle a law enforcer officer.

Imanuel Kant, placing human dignity as the most important basic norm. According to Kant, we should respect human dignity, due to a human is only creature that the goal for himself. For Kant, everyone has the duty to respect human dignity, which is formulated in command as follows: "Let treating people always as the goal at him also and never for the tool". Human dignity should be respected, should not be

25 Absori, Ahmadi, "Transplantasi Niilai Moral Dalam Budaya Untuk Menuju Hukum Berkeadilan (Prespektif Hukum Sistematik ke Non Sistematik Charles Sampford),Op-Cit

${ }^{26}$ Frans Magnis Suseno, 1987, "Etika Dasar (Masalah-masalah Pokok Filsafat Moral)", Yogyakarta. Kanisius 
utilized. It is never manipulated for the sake to achieve the goal which is located outside of the humanitarian goal. For Kant, human dignity becomes liabilities source either to ourselves and to others. ${ }^{27}$

The investigation that using violence way to get evidence or recognition of suspect is never justified, due to suspect dignity should not be violated to achieve the goal of the investigation and collecting evidence. As moral thought, ethic in justice requiring the law enforcer to obey law norms itself and also ethic in order to highlight the good and the bad in a moral manner the law enforcement officer treating the defendant in solving crimes, and once more again a good and a bad manner that referred is not only appointing to an limited aspect only, which is not directly determine ethical quality a law enforcer But the act of good or bad in the whole thing as human beings. ${ }^{28}$

Law enforcement can be achieved when justice could be achieved by law enforcement. The concept definition of justice has been often mentioned by, such as justice to put one in its place (proportional). Justice is a balance between rights and obligations and others. Similarly, classifications of justice, suppose Aristotle divide justice become commutative and distributive justice. There are also divides justice into legal justice, moral justice, and social justice ${ }^{29}$

Understanding of justice has a history of long thought. Justice is part of this writing purpose to be described. In essential, law diskursus, The trait of justice can be seen in the double meaning namely in formal terms which demands that the law goes in general, and material meaning, Demanding that every law should be in accordance with the ideals of society. ${ }^{30}$ However if reviewed in a wide context, the ideas on justice developing with an approach that different, due to the justice set out in many kinds of literature, impossible without involving themes of politic moral and law theory. Therefore, Explain the truth about justice in a singular manner and almost hard to $\mathrm{do}^{31}$

\footnotetext{
${ }^{27}$ Bertens K, 2011 "Etika biomeds", Yogyakarta Kanisius.

${ }^{28}$ Bertens K, 2011 "Etika biomeds", Yogyakarta Kanisius, Ibid

${ }^{29}$ Syamsudin, M. (Ed), 2013, Ilmu Hukum Profetik: gagasan awal, Landasan Kefilsafatan dan Kemungkinan Pengembangannya di era Post modern, Yogyakarta: Pusat Studi Hukum UII

${ }^{30}$ Frans Magnis Suseno. 'Etika Politik Prinsip-prinsip moral dasar kenegaraan Modern,” Jakarta, Gramedia Pustaka Utama, 2003. Hlm.81

${ }^{31}$ Raymond Wacks, Jurisprudece, Londen Blekstone Press Limited, 1987, hlm.179.
} 
Justice that is intended in this writing is justice that is full of moral values that appreciate decisions including in justice based on religious values (prophetic justice). Prophetic justice is justice based on religious values and sourced from Al-Quran which is full of meaning and yang Illahiyah value which appreciates in judicial decisions.

From the point of view of Islam also we are told to act fairly in solving a problem. The order among others mentioned in the Al'quran, surah An-nisa:58 "Indeed, Allah commands you to render trusts to whom they are due and when you judge between people to judge with justice" next in Al Quran Surat An-Nisa: 135 confirmed: O you who have believed, be persistently standing firm in justice, witnesses for Allah, even if it be against yourselves or parents and relatives. Whether one is rich or poor, Allah is more worthy of both. So follow not [personal] inclination, lest you not be just. And if you distort [your testimony] or refuse [to give it], then indeed Allah is ever, with what you do, Acquainted.

According to Al-syathiby, That the discussion of legal purposes oriented to utilization or your people has to be prioritized of very large portions, law enforcer and Islam is law aspect which is contained repository the guidance of life (instruction and prohibition) Set a regulation in society. In relation to the law aspect, that justice of Islamic law was sourced from the fairest because virtually god who executes (quillman bilqish), therefore in the human actions will be accounted by Him on the day of justice like his words in Al-Qur'an Surah-Nisa. Ayat 110.

The practice of justice as it is certainly justice full of meaning and values Illahiyah who animates in an award. Justice transcendental indeed spirit and his soul is very ideal, therefore the parameter constructed is justice and taught as ordered by AlQur'an. Holly Quran is primary guidance in formulated values of justice in the award. Justice of such as these is exemplified by the prophets and the rosul. The concept of justice as it is intended as justice prophetic it is certainly is in line and can synergies with other the value of justice ${ }^{32}$

Justice prophetic its embodiment in judicial decisions were always the foundation which is in the head of the judge decision, " Justice Based on the only one God" Which is supposed to be the soul of the verdict. Therefore justice based on

\footnotetext{
${ }^{32}$ Syamsudin, M. (Ed), 2013, Ilmu Hukum Profetik: gagasan awal, Landasan Kefilsafatan dan Kemungkinan Pengembangannya di era Post modern, Op-cit
} 
moral value and profit justice was needed to law enforcement in Indonesia with would not rule out positive laws that exist, thus law enforcement that could be embodied in a frame judicial and give a sense of essential justice.

\section{CONCLUSION}

The systematic law approach viewed that law is not from God or nature but the law is born from human which is based on provisions to separate law and morals. The flow of positivism starts from the way teaching that characterized law is managing, applies to a whole, and determined by state authority. In relation with law enforcement in Indonesia during this day still struggling systematic law approach, Which made law out of the moral value and religious, so that become instrumentalist tools only, a funnel of legislation and knocks on hammer from text article which is formulated authority area therefore far from the sense of justice.

The law approach of non-systematic assumed that social science is developed from a societal behavior pattern. So that between law and morals can not be separated. In relation to law enforcement in Indonesia, that law enforcer is not justified if only notice consideration of the articles, but should be considering social dimension and humanity in a case. In order that law enforcement through sociological perspective are many variables involved in the sense of social with humanitarian struggle, so that law enforcer besides working based on norms law, Must be supported by the moral norms and values that the integrity of judicial as justice institution and righteousness really operating in domains of the human right, so that able to give sense of justice.

The importance of moral value in law enforcement intended as the principal or orientation utilities of law enforcer officer, about how to do the duty of law enforcer that becomes its responsibility properly. The goal is to law enforcement can take responsible action (Do not lose orientation) dealing with several things (values and moral norms) that Faced during the judicial process that would give justice to the society. Justice that intended is justice that is full of moral values and religious (prophetic justice). Prophetic justice is justice based on religious values that are resourced from Al-Quran, full of meaning and Illahiyah values that animate in judicial decisions.

\section{REFERENCES}


Absori, Ahmadi, "Transplantasi Niilai Moral Dalam Budaya Untuk Menuju Hukum Berkeadilan (Prespektif Hukum Sistematik ke Non Sistematik Charles Sampford), Prosiding Konferensi Nasional ke 6 Asosiasi Perogram Pasca Sarjana Perguruan Tinggi Muhammadiyah (APPPTM) Yogyakarta2017

Absori, Kelik Wardiono dan Saeful Rahman, Hukum Profetik: Kritik Terhadap Paradigma HukumNon-sistematik, Yogyakarta, genta Publising, 2015,hlm.213.

Anthon F. Susanto, Ilmu Hukum Non Sistematis: Pondasi Filsafat Pengembangan Hukum di Indonesia, Yogyakarta, Gentha Publishing, 2010, hlm:15

Benard Arief Sidarta, Hukum dan logika, Bandung, Alumni, 2002, hlm. 10.

Bernard L. Tanya dkk, 2010, Teori Hukum Strategi Tertib Manusia lintas Ruang dan Generasi, Yogyakarta, Genta Publising

Bertens, 2011, “Etika Biomedis”, Yogyakarta: Kanisius

Hukum Progresif : Prespektif Moral dan Kritis dalam "dekontruksi dan pemikiran hukum progresif” konsorsium Hukum Progresif Universitas Diponegoro, Yogyakarta Thafa Media, 2013, hlm. 44.

Edward O. Wilson, Consilience The Unity of Knowledge, (New York: Vintage Books, A Division of RandownHouse, inc). 1 ed on 1999, hlm.2.

Francisco Javier Foncesca, "Dificiences of the rule Of Law an the Legal Culture, and its Relationship to Ander Development", Asian Journal of Law and Economics, 6(2), 2015, hlm.2032.

Frans Magnis Suseno, 1987, "Etika Dasar (Masalah-masalah Pokok Filsafat Moral)", Yogyakarta. Kanisius

"Etika Politik Prinsip-prinsip moral dasar kenegaraan Modern," Jakarta, Gramedia Pustaka Utama, 2003. Hlm.81.

K. Dimyati, Absori, K Wardiono, "Pemetaan Dan Jasa hakim" Profil Hakim Dalam Penegakan keluhuran, Martabat dan Kehormatan Profesi. Proseding Konferesnsi Nasional Ke 2 Asosiasi Program Pasca Sarjana Perguruan Tinggi Muhammadiyah (APPPTM) Yogyakarta 2015

Lawrence Meil Friedman, Law in Society; an Introduction (Prencite-Hall Fondation of Modern Sosiology Series, Eglewood Cliffts Stanford University, New Jersey, 1979. hlm:7

Muhammad Agus Santoso, Hukum, Moral dan Keadilan, Jakarta Kencana Prenada Media, 2012, hlm.90.

Raharjo, Agus. 'Hukum dan Dilema Pencitraan: Transisi Pradigmatis Ilmu Hukum dalam Teori dan Praktik”. Jurnal Hukum Pro Justicia. Vol. 24. No. 1 January 2006. Bandung: Faculty of law of Universitas Parahyangan 
Raymond Wackd, Jurisprudece, Londen Blekstone Press Limited, 1987, hlm.179.

Robin M. Williams, "Values: Concept of Falues" dalam The International Ecylopedia of The Social Scoiences, The Magmillan Publisher, London, 17 Vol, 1972, Editor: David L. Sills, disalin oleh konsorsium Antar-bidang Depdikbud Jakarta, 1982, hlm.251-252.

. Satjipto Rahadjo, 2002. Indonesia inginkan penegak hukum progresif. Kompas.

2003. Sisi lain dari hukum di Indonesia. Jakarta. Buku Kompas.

2006. Membedah hukum progresif. Jakarta. Kompas

2007. Membedah Hukum Progresif, Jakarta Penerbit Buku Kompa,.hlm.151

Syamsudin, M. (Ed), 2013, Ilmu Hukum Profetik: gagasan awal, Landasan Kefilsafatan dan Kemungkinan Pengembangannya di era Post modern, Yogyakarta: Pusat Studi Hukum UII. 